\title{
SURFACE FINISHING BY ROLLER BURNISHING USING APPARATUS OF PERMANENT MAGNET
}

\author{
János Kodácsy, János Líska, Zsolt Kovács
}

Original scientific paper

The authors present the results of experimental and developing work regarding Magnetic Aided Roller Burnishing (MARB) process and apparatus using permanent magnet that operates by surface finishing, deburring and by the strain hardening effect. Additionally, the paper demonstrates the benefit of using the apparatus with permanent magnet against using the apparatus with electro magnet. Finite Element Method (FEM) modelling software system was used in support of the experimental results.

Keywords: burnishing; deburring; FEM; magnetism; simulation; strain hardening

\section{Završna obrada površine poliranjem valjkom uz primjenu naprave s permanentnim magnetom}

Izvorni znanstveni članak Autori predstavljaju rezultate eksperimentalnog i razvojnog rada koji se odnosi na postupak poliranja pomoću magnetičnog valjka (MARB) i napravu s permanentnim magnetom $u$ završnoj obradi površine, brušenjem i učinka otvrdnjavanja. Dodatno se demonstrira korist od primjene uređaja $s$ permanentnim magnetom u odnosu na uređaj s elektro magnetom. Podrška eksperimentalnim rezultatima dana je primjenom softvera za modeliranje metodom konačnih elemenata (FEM).

Ključne riječi: brušenje; FEM; magnetizam; otvrdnjavanje; poliranje; simulacija

\section{Introduction}

There are a lot of known solutions of mechanical roller-burnishing technologies $[1 \div 4]$. In this paper, the results of a comprehensive research work of roller burnishing metal parts in magnetic field will be presented. This recent fine finishing process is based on the following concept: the surface roughness of steel workpieces made of annealed steel or other ductile, magnetisable materials can be considerably decreased by burnishing in magnetic field using hardened steel balls. In addition, the hardness of the surface layer remarkably increases and there is a possibility to eliminate fine burrs. The necessary pressure and relative speed between the tools and the workpiece are ensured by the magnetic force using apparatus with electro or permanent magnet.

\section{Magnetic Aided Roller Burnishing of flat surfaces using electro magnet}

Magnetic Aided Roller Burnishing of flat surfaces was designed and adapted to a vertical milling machine. The design is illustrated in Fig. 1a, while the experimental setup can be seen in Fig. 1b. During rolling, the bearing (HRC64) balls were kept between the burnished surface and the conical end of the rotating arbor (as a magnetic core) by magnetic force. In the course of the burnishing tests, ferromagnetic construction steels $(\mathrm{HB}=150)$ and non-ferromagnetic Al-alloy workpiece materials were investigated $[5 \div 8]$. As a result the ferromagnetic steel was burnished with better results than the non-ferromagnetic Al-alloy material, because of the higher magnetic force and continuous ball rotation. Therefore each ball has a point of rotation where it comes into contact with the workpiece. By the machining, a Minimal Quantity Lubrication (MQL) system with synthetic oil of $20^{\circ} \mathrm{E}$ viscosity was used.

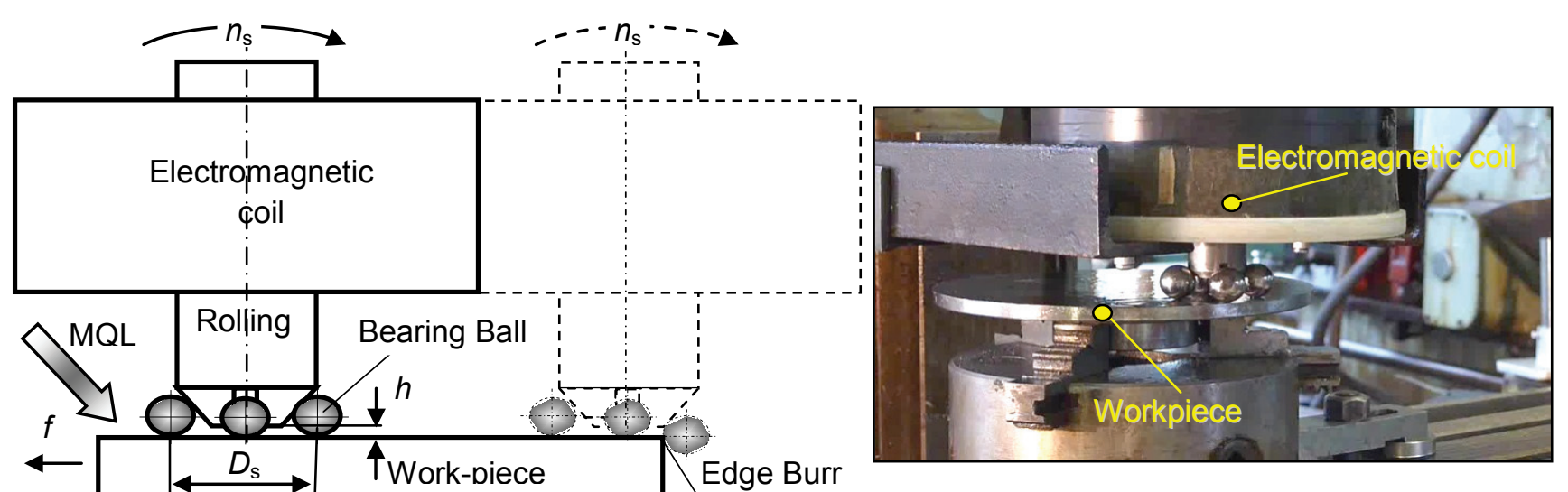

a) b)

Figure 1 Design of Magnetic Aided Roller Burnishing of flat surface (a) and the photo of the equipment (b) 


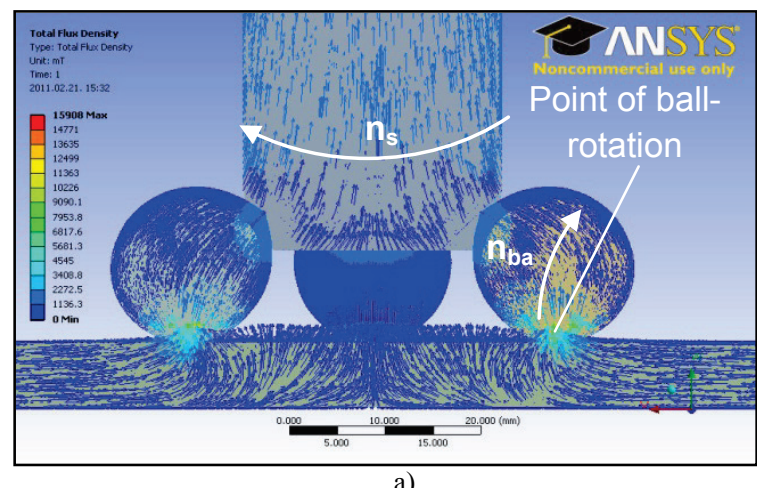

Figure 2 Arrangement of magnetic field lines for steel (a) and Al-alloy (b) workpiece materials when burnishing flat surfaces

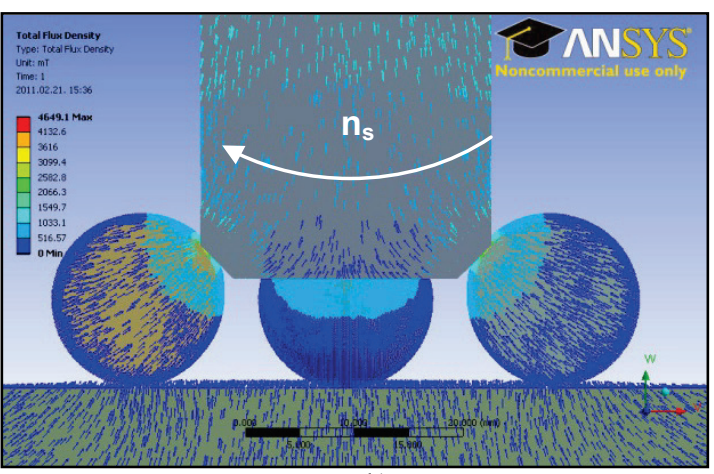

b)

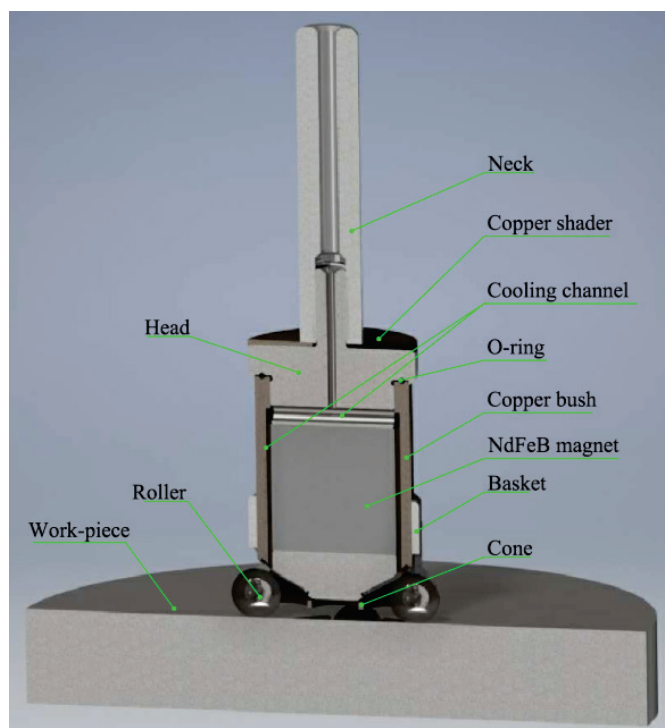

Figure 3 The MARB tool with permanent magnet

During the tests, the electrical parameters of the electromagnet were: charging voltage $U=40 \mathrm{~V}$, amperage $I=5 \div 20$ A (adjustable direct current) generating $B=$ $1,3 \div 1,8 \mathrm{~T}$ magnetic induction in the $h \approx 3 \mathrm{~mm}$ gap. The electromagnetic coil has 800 winds with $\varnothing 2$ coil-wire and the measure of the magnetic core is $\varnothing 25 \times 100 \mathrm{~mm}$.

By burnishing flat surfaces, the arrangement of the magnetic field lines for ferromagnetic (construction steel) and non-ferromagnetic (Al-alloy) workpiece materials is illustrated in Fig. 2. For modelling the ANSYS 11.0. Workbench, Magneto static module FEM software was used. In Fig. 2 it is visible when rolling ferromagnetic materials, the point of ball rotation occurs by the magnetic adhesion, while in case of non-ferromagnetic materials it does not.

\section{Magnetic Aided Roller Burnishing of flat surfaces using permanent magnet}

By the MARB with electro magnet, the process automation is a relevant problem, for example the usability of the apparatus on the CNC machine. Therefore, a new MARB tool with permanent magnet was developed. Fig. 3 shows the tool-parts and the 3D image of the tool.

The new tool can be positioned in the tool holder and can be taken to working position according to the machining process. Fig. 4 shows the tool after burnishing

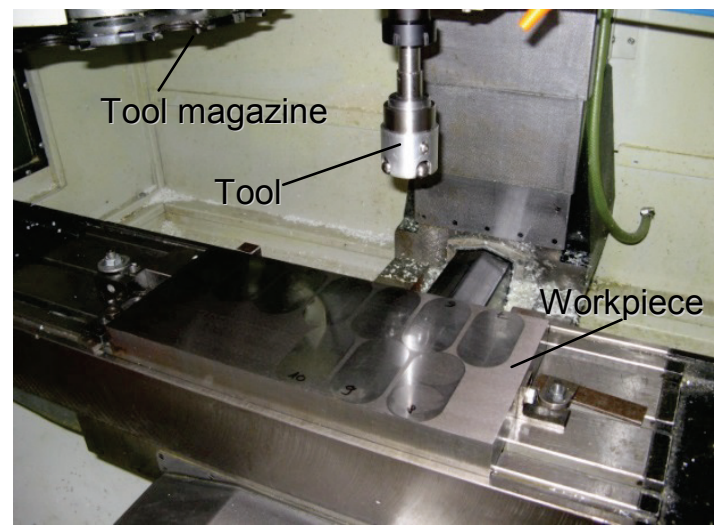

Figure 4 The MARB tool during roller burnishing

in the tool holder. The shiny surfaces of the workpiece are burnished surfaces.

During roller burnishing of ferromagnetic materials (Fig. 2a) the magnetic field lines are condensed towards the direction of rolling arbour. As a result, the ball is attracted toward the centre line by having the arbour tapered and by lifting it in the right height $h$ from the surface of the workpiece while pushing the surface by force $F_{\text {nw }}$ (Fig 5a).

Force $F_{\text {nw }}$ can be calculated by using Eq. (1), while the distance between the tool nose and the workpiece $(h)$ and the $\alpha$ angle between vectors $F_{\mathrm{r}} ; F_{\mathrm{ns}}$ can be calculated by Eq. (2).

$$
F_{\mathrm{nw}}=F_{\mathrm{r}} \cdot \tan \alpha, \quad(\mathrm{N})
$$

$h=r_{\mathrm{g}} \cdot(\sin \alpha+1)-b . \quad(\mathrm{mm})$

From this:

$$
F_{\mathrm{nw}}=F_{\mathrm{r}} \cdot \tan \left(\arcsin \left(\left(\frac{h+b}{r_{\mathrm{g}}}\right)-1\right)\right) .
$$

According to Eq. (4), $F_{\mathrm{r}}$ at a given permanent magnetic tool depends only on the magnetic-field strength $(H)$ and on its gradient $(\partial H / \partial r)$, which can be changed by value $h$. 
Evidently, the volume of the balls $\left(V_{\mathrm{g}}\right)$ and their permeability $(\mu)$ do not change during the roller burnishing process.

$$
F_{\mathrm{r}}=V_{\mathrm{g}} \cdot H \cdot\left(\frac{\partial H}{\partial r}\right) \cdot\left(\mu-\mu_{0}\right) .
$$

In Fig. 5a, the $F_{\mathrm{m}}$ magnetic force constituted between the magnetic ball and the workpiece is increasing the roller burnishing force in a small extent.

The force measurements were preceded by calculations and the results are shown in Fig. 5b.The radius of the balls of the tool construction is $r_{\mathrm{g}}=8 \mathrm{~mm}, b=7 \mathrm{~mm}$ and

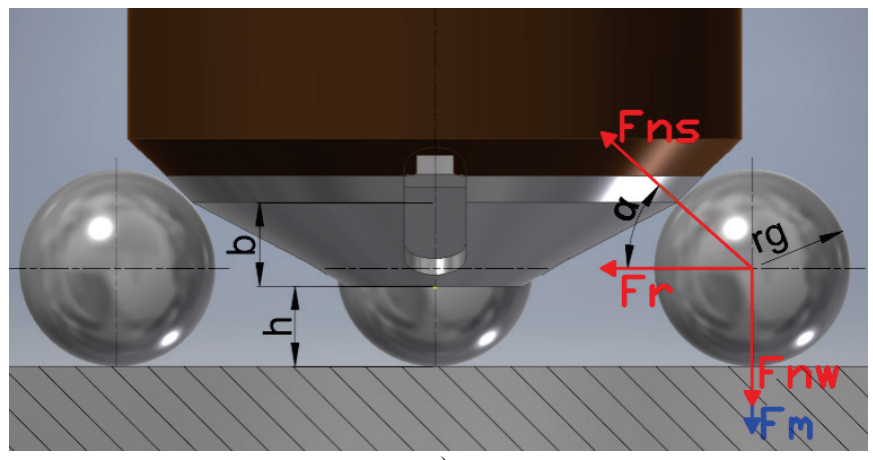

Figure 5 Vector figure of roller burnishing (a) and the change of $F_{\text {nw }} / F_{\mathrm{r}}$ depending on $h$

The change of the roller burnishing force depending on tool distance $(h)$ is shown in Fig 6 . The measurements are initiated by the distance of the workpiece tool nose $h$ $=10 \mathrm{~mm}$ without balls. Without the balls the sinuous diagram in the figure is in the negative domain. This means that the tool and the workpiece are attracted. After placing the balls into the work space, positive force value is given. From that point the tool is not attracting the workpiece but pushing the workpiece by the balls. Then the tool is approached gradually to the surface of the workpiece until the gap reaches $h=2 \mathrm{~mm}$. In this position, negative force is registered to be similar to the position without the balls. This means the pressure on the surface by the balls and the peak started to attract the workpiece. According to the expectations, the maximal burnishing force was measured at $h=8 \mathrm{~mm}$. KISTLER 9125A24A2 force and torque measuring instrument is used for the measurements.

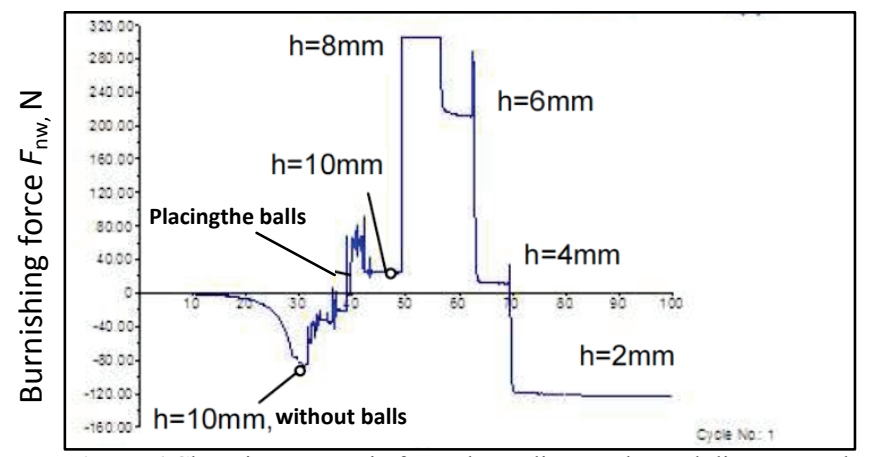

Figure 6 Changing magnetic force depending on the tool distance to the workpiece

Considering the expected force and geometrical data, test burnishing could be carried out, but the applied tool the size of the $\mathrm{NdFeB}$ magnet part is $\varnothing 40 \times 40$. The calculations are initiated with $h=4 \mathrm{~mm}$ gap and tested up to $h=9 \mathrm{~mm}$. At $h=9 \mathrm{~mm}$, equation (3) does not have valuable result because of $\alpha=90^{\circ}$. If height $h$ is being increased, the burnishing force $F_{\mathrm{nw}}$ is also increasing, however, as the diagram shows the contact and the force transfer become uncertain over $h=8 \mathrm{~mm}$. During the measurements, similar results are given. These values allow the roller burnishing of the free form surfaces of low wave to avoid having the burnishing force reduced and resulting in uneven surface roughness.

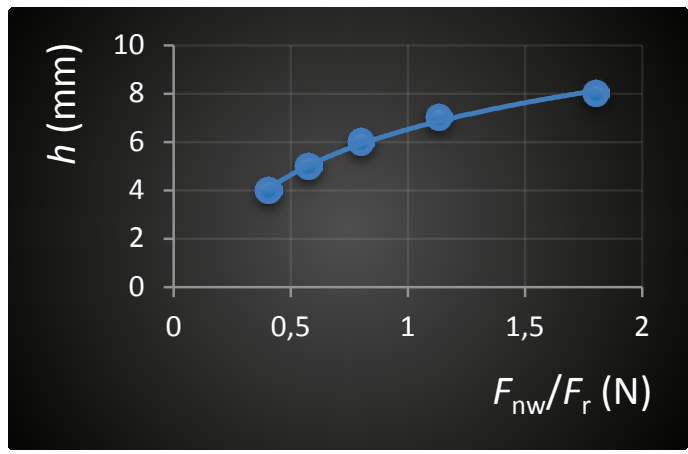
certain revolutions, the centrifugal force is increasing and can critically reduce the burnishing force. While testing, the rev are increased from $n=100 \mathrm{rev} / \mathrm{min}$ to $n=1200$ rev/min. The diagram of Fig. 7 shows that the force decreases by $30 \%$. This decline does not affect the safe use of the tool.

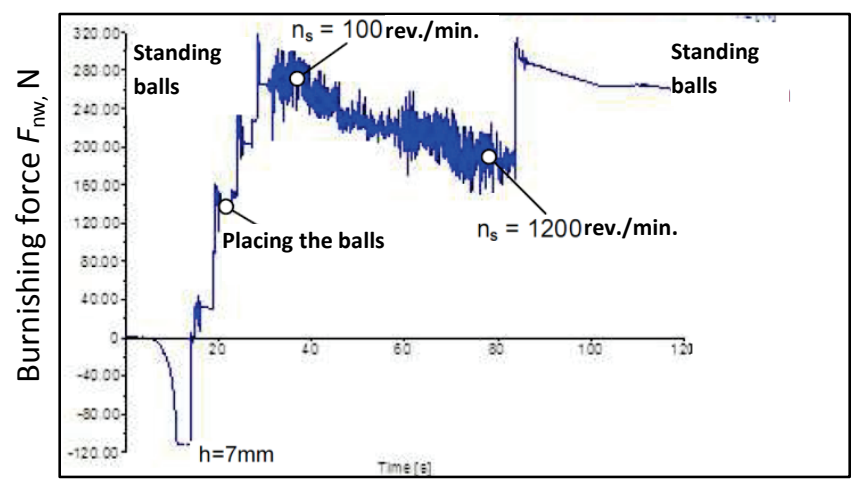

Figure 7 Changing magnetic force by changing tool revolution

\section{Practice results of MARB}

As it was mentioned, the surface roughness can be improved after the MARB, the burnished surface layer hardens and the burr can be removed from the side of burnished surface.

Some of these practical results should be presented as follows.

The surface roughness after MARB process plate $\mathrm{C} 45$ should be machined in normalized conditions (HB 150) by $\mathrm{CNC}$ milling machine after grinding in more technological variants. The two variants of technological 
parameters of burnishing are presented in Tab. 1, the results are shown in Fig. 8.

Table 1Surface burnishing conditions at permanent magnet after grinding

\begin{tabular}{|l|l|c|c|}
\hline \multicolumn{2}{|l|}{ Technology } & 1 & 2 \\
\hline Tool revolution & $n_{\mathrm{s}} / \mathrm{rev} / \mathrm{min}$ & 130 & 413 \\
\hline Tool diameter & $D_{\mathrm{s}} / \mathrm{mm}$ & $\varnothing 44,5$ & $\varnothing 44,5$ \\
\hline Burnishing speed & $v_{\mathrm{b}} / \mathrm{m} / \mathrm{min}$ & 18,2 & 57,7 \\
\hline Feed speed & $v_{\mathrm{f}} / \mathrm{mm} / \mathrm{min}$ & 18,23 & 62,87 \\
\hline Feed rate & $f_{\mathrm{g}} / \mathrm{mm} / \mathrm{ball}$ & 0,036 & 0,036 \\
\hline Tool distance & $h / \mathrm{mm}$ & 7 & 7 \\
\hline
\end{tabular}

The ball diameter in both cases was $d=\varnothing 16 \mathrm{~mm}$, and the ball bearings were made from magnetisable steel. By the machining, a Minimal Quantity Lubrication (MQL) system with $20^{\circ} \mathrm{E}$ synthetic oil was used.

Grinding parameters were applied as follows: $v_{\mathrm{c}}=35 \mathrm{~m} / \mathrm{s}, w_{\mathrm{w}}=30 \mathrm{~m} / \mathrm{min}$. Flat-grinding machine was used, the grinding tool dimension was $\varnothing 300 \times 30 \mathrm{~mm}$ and the grain was $\mathrm{Al}_{2} \mathrm{O}_{3}$ with $280 \mu \mathrm{m}$ size.

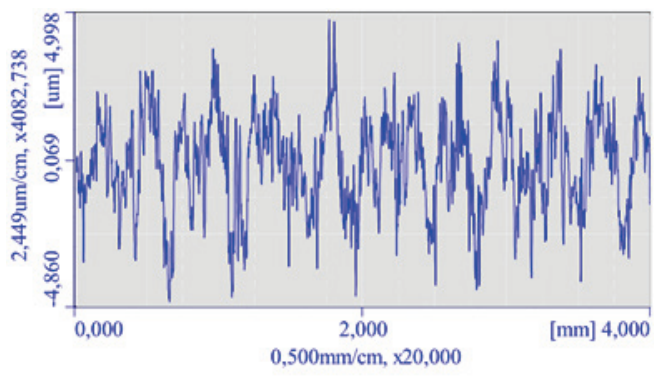

Surface after grinding (a)

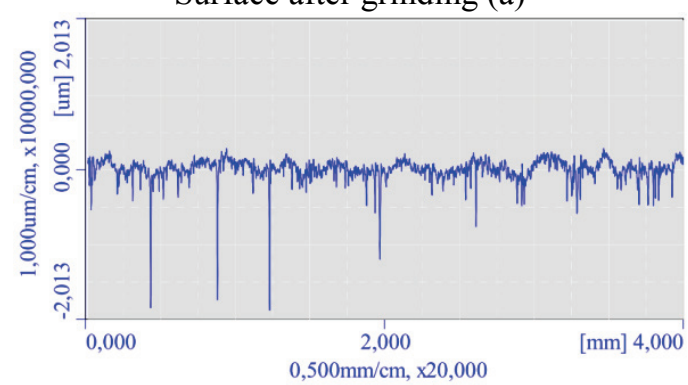

Surface after MARB technology 1(b)

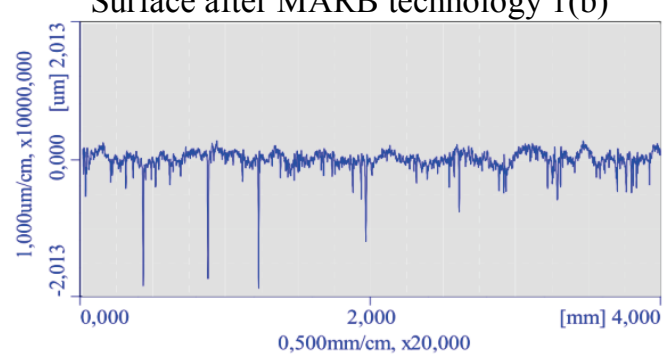

Surface after MARB technology 2(c)

\begin{tabular}{|c|c|c|c|}
\hline \multicolumn{4}{|c|}{ Parameter Table } \\
\hline $\begin{array}{c}\text { Surface } \\
\text { roughness }\end{array}$ & $\begin{array}{c}\text { Average after } \\
\text { grinding }\end{array}$ & $\begin{array}{c}\text { Average after } \\
\text { technology 1 }\end{array}$ & $\begin{array}{c}\text { Average after } \\
\text { technology 2 }\end{array}$ \\
\hline$R a / \mu \mathrm{m}$ & 1,296 & 0,078 & 0,112 \\
\hline$R q / \mu \mathrm{m}$ & 1,596 & 0,104 & 0,187 \\
\hline$R z / \mu \mathrm{m}$ & 8,226 & 0,757 & 1,857 \\
\hline$R t / \mu \mathrm{m}$ & 9,389 & 0,976 & 3,308 \\
\hline
\end{tabular}

Figure 8 The Surface roughness and its parameters after grinding (a) and MARB $(b, c)$
Fig. $9 \div 10$ show the evaluation of $R a$ and $R t$ before and after MARB during changes of burnishing speed $-v_{\mathrm{b}}$ ( 1 and 2 technology).

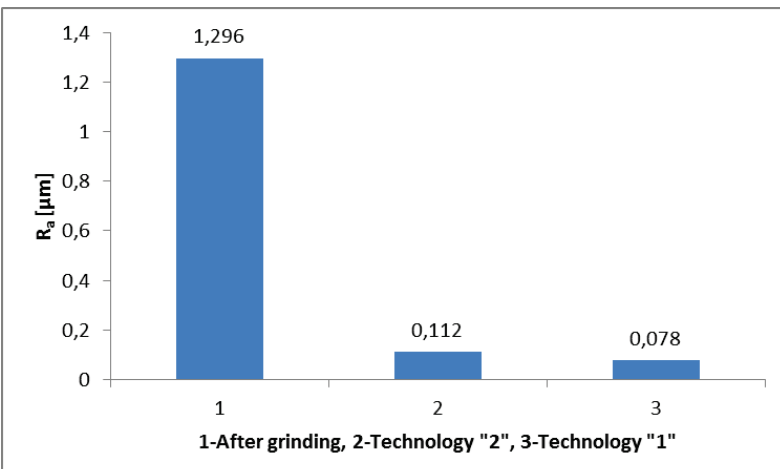

Figure 9 The surface roughness average $(R a)$ evaluation

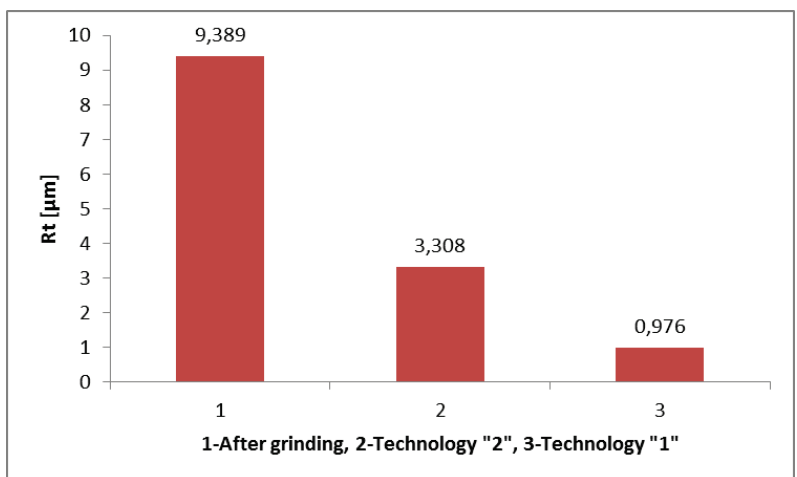

Figure 10 The surface roughness total height $(R t)$ evaluation

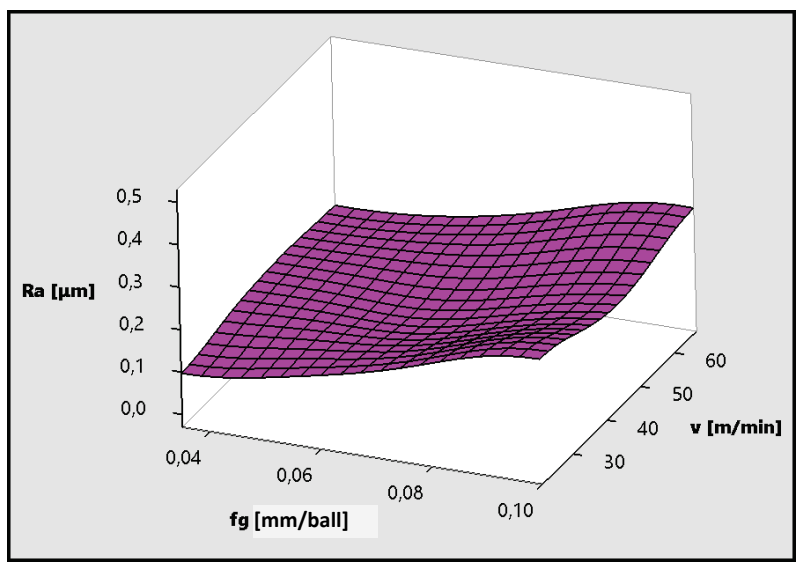

Figure 11 3D map of surface roughness average after MARB

Fig. 11 shows the MARB evaluation on surface roughness $(R a)$, if the feed rate $0,03<f_{\mathrm{g}}>0,1(\mathrm{~mm} / \mathrm{ball})$ and the burnishing speed $18<v_{\mathrm{b}}>63(\mathrm{~m} / \mathrm{min})$ was changed.

\section{The hardening by MARB}

Using MARB in one stroke, the hardness of the surface layer can increase one and a half times more at $\Delta r=20 \div 30 \mu \mathrm{m}$ thickness (Fig. 12). By the machining, the ball diameter was $D_{\mathrm{g}}=8 \mathrm{~mm}$; the forming speed: $v_{\mathrm{b}}=40 \mathrm{~m} / \mathrm{min}$; the forming force: $F_{\mathrm{nw}}=90 \mathrm{~N} / \mathrm{ball}$; the workpiece material: C45 annealed. 


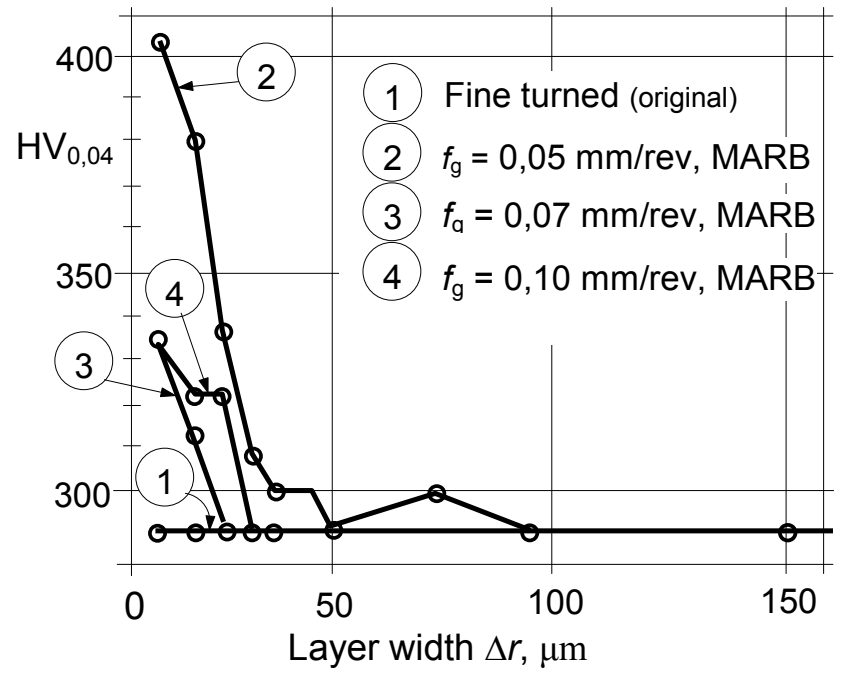

\section{Deburring by MARB}

The process is also suitable for eliminating fine burrs from the edges of flat surfaces, because the balls - in the case of ductile workpiece materials - may press the burrs into the workpiece-edge or the extra sharp edge to the other side of the workpiece (see Fig. 1a). The machining makes the sliding movements $\left(v_{\mathrm{s}}\right)$ of the slippery surfaces easier and impedes the possible jam in the guide way of metal parts (Fig. 13). Actually, this process is the magnetic version of the edge rolling operation of sheet stocks using pinch rolls to remove burrs or reroll the material into the edges $[9,10]$.

Figure 12 The hardening of surface layer after MARB
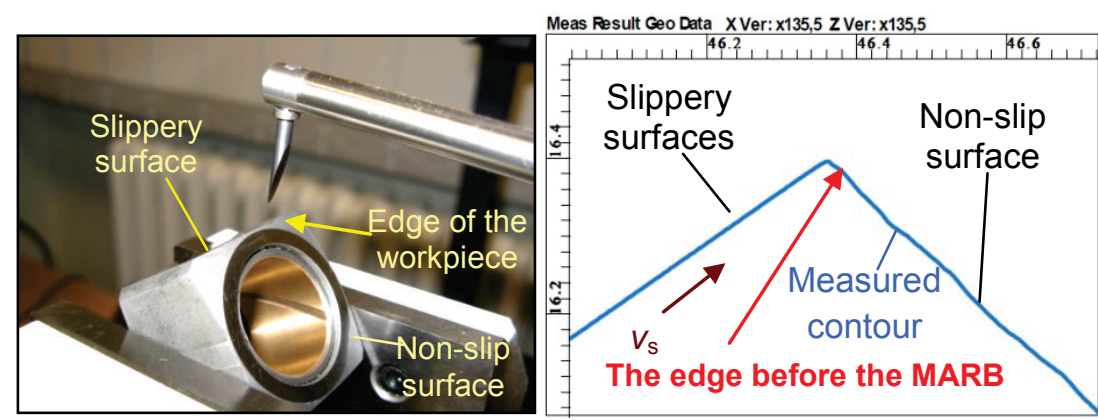

Figure 13 Slippery surface measurement and its evaluation

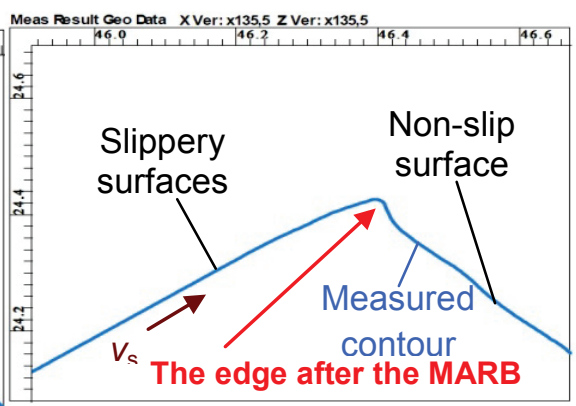

The edge after the MARB

\section{Conclusion}

Experimental devices were constructed by the authors for performing finish machining tests by Magnetic Assisted Roller Burnishing (MARB) process, using steel and Al-alloy specimens. During the tests, geometrical and kinematical parameters of the surface quality were investigated and determined in detail.

The main results obtained in this experimental work are summarised as follows:

- Based on the results of the experiments, it has been proved that this process can be effectively and economically used for finishing (burnishing) flat surfaces of magnetisable metal workpieces. The result depends on the technological conditions and the design of the tool.

- In addition to the decrease of the surface roughness, the hardness of the surface layer may considerably increase within the depth of $10 \div 30 \mu \mathrm{m}$ due to the strain hardening.

- In some cases, MARB technology gives opportunity for improving of sliding properties by burnishing of burrs or sharp edges.

MARB tool with newly developed permanent magnet allows the integration of technology into automated machining processes

\section{Acknowledgement}

The authors would like to thank the National Development Agency (Project No.: TÁMOP 4.2.1./B09/1/KONV-2010-0003) and the Foundation for Development of Automation of the Machine Industry endowed by the Faculty of GAMF of Kecskemét College for financial support.

\section{References}

[1] www.fette.de

[2] www.hegenscheidt-mdf.de

[3] European patent. Patent No.:172 7648

[4] Hungarian patent. Patent No.:227 622

[5] Kodácsy, J.; Danyi, J.; Szabó, A.; Fülöp, Gy. Magnetic Aided Roller Burnishing Metal Parts. $/ / 7^{\text {th }}$ International Conference on Deburring and Surface Finishing, UC Berkeley (USA), 2004, pp. 375-378.

[6] Sebestyén, I.; Kodácsy, J. Magnetic Field and Force Calculation for Magnetic-Aided Device. // IEEE Transaction on Magnetic. 36, 4(2000), pp. 1837-1840. DOI: 10.1109/20.877802

[7] Kodácsy, J.; Szabó, A.; Danyi, J. The State of the Art and Recent Results of Magnetism-Aided Surface Improving and Edge Finishing Processes. // $10^{\text {th }}$ International Research/Expert Conference "Trends in the Development of Machinery and Associated Technology", Lloret de Mar, Barcelona, Spain, 2006, pp. 85-88.

[8] Kodácsy, J.; Szabó, A.; Danyi, J.; Sebestyén, I. Investigation of Magnetic Field by Finite Element Method in MA Roller Burnishing Process. // $8^{\text {th }}$ International Research/Expert Conference "Trends in the Development 
of Machinery and Associated Technology", Neum, B\&H, 2004, pp. 263-266.

[9] Gillespie, L. R. K. Deburring and Edge Finishing Handbook, ASME Press, New York, 1989.

[10] Kodacsy, J.; Liska, J. Magnetic Assisted Roller Burnishing and Deburring of Flat Metal Surfaces. // Advanced Materials Research. 472-475, (2012), pp. 908-911. DOl: 10.4028/www.scientific.net/AMR.472-475.908

\section{Authors' addresses}

János Kodácsy, Dr.

Pallasz Athéné University, GAMF Faculty of Engineering and Computer Science, Department of Vehicle Engineering H-6000 Kecskemét, Izsákiút 10, Hungary

kodacsy.janos@gamf.kefo.hu

János Líska, Dr.

Pallasz Athéné University, GAMF Faculty of Engineering and Computer Science, Department of Vehicle Engineering H-6000 Kecskemét, Izsákiút 10, Hungary

liska.janos@gamf.kefo.hu

\section{Zsolt Kovács}

Pallasz Athéné University, GAMF Faculty of Engineering and Computer Science, Department of Vehicle Engineering

H-6000 Kecskemét, Izsákiút 10, Hungary

zsolt.kovacs@gamf.kefo.hu 